\title{
"Äidinpalkka"
}

\author{
ANTERO PERÄLÄINEN, Väestöliitto \\ JARL LINDGREN, Väestöpoliittinen Tutkimuslaitos
}

Meidän maassamme on viime vuosina useassa eri yhteydessä keskusteltu julkisuudessa äidinpalkasta, pieniä lapsia hoitaville äideille maksettavasta tuesta, hoitotuesta. Kun on käynyt ilmi, että tämän käsitteen sisältö ei ole vakiintunut, vaan sillä saatetaan tarkoittaa hyvinkin erilaisia järjestelmiä, on tämän kirjoituksen tarkoituksena esittää lyhyesti, mitä itse asiassa tarkoittavat ne muiden maiden tukimuodot, joita meillä on kutsuttu äidinpalkaksi tai äidinpalkkioksi. Lisäksi tarkastellaan meillä julkisuudessa esitettyjä ehdotuksia ja ajatuksia tämänlaatuisesta tuesta, sen motiiveista ja suuruudesta.

\section{Esikuva Ranskasta}

"Aidinpalkka" perhepoliittisena ideana ja tukimuotona on kotoisin Ranskasta. Siellä se otettiin käytäntöön ensimmäisen kerran vuonna 1931, kun eräs teollisuuslaitos Pohjois-Ranskassa maksoi henkilökunnalleen erisuuruisen tuen riippuen siitä oliko äiti kotona vai ei. Vuodesta 1938 tämä tuki on ollut lakisääteinen. Nykyisin on voimassa kaksi erilaista järjestelmää. Palkansaajaperheet, joissa on vain yksi tulonsaaja tai joissa vaimon ansiot ovat vähäisiä, saavat ns. yhden palkan lisää (allocation de salaire unique), jos perheessä on yksi alle viisivuotias lapsi tai vähintään kaksi lasta. Viljelijäperheille suoritetaan ns. kotona olevan äidin lisää (allocation de la mère au foyer), jos perheessä on vähintään kolme lasta; tämä tuki on hieman pienempi kuin palkansaajien vastaava tuki ja sitä suoritetaan kolmannesta kuudenteen lapseen.
Tyypillistä palkansaajien järjestelmälle on, että aviomiehen suuretkaan tulot eivät ole esteenä yhden palkan lisän saamiselle; äidillä itsellään sen sijaan saa olla vain vähäisiä tuloja. Tilastot osoittavat, että suurin osa lapsilisää saavista perheistä saa Ranskassa myöskin äidin palkkaa. Allaoleva asetelma osoittaa kaavamaisesti miten tämä äidinpalkkioksi meillä kutsuttu tuki ja lapsilisä yhdessä muodostavat palkansaajan perheelle annetun tuen $(\mathrm{mk} / \mathrm{kk})$ :

$\begin{array}{cccc}\begin{array}{c}\text { Lasten } \\ \text { luku }\end{array} & \text { Lapsilisä } & \begin{array}{c}\text { \%idin- } \\ \text { palkkio, }\end{array} & \text { Yhteensä } \\ 1 & 0 & 33 & 33 \\ 2 & 67 & 66 & 133 \\ 3 & 168 & 82 & 250 \\ 4 & 269 & 82 & 351 \\ 5 & 370 & 82 & 452 \\ 6 & 470 & 82 & 552\end{array}$

"Äidinpalkkion" katsotaan Ranskassa nykyisin olevan olennainen osa perhekustannusten tasausta ilman, että sillä olisi mitään erityistä tarkoitusperää (Hochard 1963, 87). Kansainvälisen sosiaaliturvajärjestön raportissa on asia selitetty niin, että yhden palkan lisä ei ole luonteeltaan äidille tarkoitettu avustus vaan pikemminkin lapsen elatukseen tarkoitettu lisäavustus (ISSA Report XVI 1965, 32). Tämän perusteella voitaneen todeta, ettei tämän tuen tarkoituksena ole niinkään ollut erityisen korvauksen maksaminen äidille hänen kotonaan suorittamastaan työstä, kuten meillä on joskus sanottu, vaan pikemminkin perhekustannusten tasauksen tehostaminen niissä perheissä, joissa tuen tarpeen on arveltu olevan suurimman. 
Kun varsinaista lapsilisää ei Ranskassa makseta lainkaan ensimmäisestä eikä yhdestä lapsesta on äidinpalkan avulla Ranskassa voitu tukea enemmän niitä lapsiperheitä, joissa on useita pieniä lapsia mutta myös perheitä, joissa on vain yksi tulonsaaja. Siihenhän äidinpalkan nimikin syhden palkan lisäs viittaa. Samalla on voitu tehostaa perhekustannusten tasausta keskitasoa suurempiin - nimenomaan kolmilapsisiin perheisiin nähden - rajoittamalla yksilapsisten perheiden tuki vain niihin tapauksiin, joilla on alle viisivuotias lapsi huollettavana.

Ranskan Perhejärjestöjen Liitto on vuoden 1963 joulukuussa määritellyt äidinpalkkajärjestelmän vastaisen kehityksen suuntaviivat. Se on ehdottanut, että vastedes myönnettäisiin vain kotonaolevan äidin lisää ja että sen määrä olisi aluksi $70 \%$, myöhemmin $100 \%$ pohjapalkasta. ${ }^{1}$ Edellytyksenä olisi, että perheessä on kotona yksi alle 6-vuotias lapsi tai kolme lasta ilman ikärajoituksia. Jos äiti on puolipäivätyössä, äidinpalkan määrä voisi olla puolet siitä, mitä kotona oleva äiti saa. Aidinpalkka voitaisiin ottaa lukuun laskettaessa perheen verotettavaa tuloa sekä äidin eläkettä.

Viranomaisten taholta on kuitenkin Ranskassa suhtauduttu äidinpalkkaan pidättyvästi. Aidinpalkan suuruus on pysynyt muuttumattomana monena vuotena ja sen suhde lapsilisään on heikentynyt.

\section{Äidinpalkka muissa maissa}

Muissa maissa äidinpalkkaan verrattavat tukimuodot ovat hyvin harvinaisia. Belgiassa maksettiin vuosina $1949-$ 1957 kotona olevan äidin lisää palkansaajaperheille, mutta sen määrä oli vaatimaton, vain noin kuudes osa lapsilisästä. Sen jälkeen Belgiassa toimiva perhejärjestö on esittänyt äidinpalkkaa maksettavaksi vähävaraisille perheille, joilla on yksi tai useampia pieniä lapsia ja äiti on kotona (Ligue des familles... 1959, 19).

I tävallassa saavat kaikki kahden tai useamman lapsen perheet äidinpal-

1 Noin $110-160 \mathrm{mk}$. kan nimistä tukea lapsilisän lisäksi, olipa äidillä ansioita tai ei. Puolass a suoritetaan noin puolen lapsilisän suuruista vaimokorotusta äideille, joilla on vähintään yksi alle kahdeksanvuotias lapsi, mikäli he itse hoitavat lasta. Is la nn is s a kutsutaan yksinäisille äideille maksettavaa erityislapsilisää äidinpalkan nimellä.

Myöskin Ruotsissa on äskettäin ollut esillä ajatus kaikille pieniä lapsia hoitaville äideille maksettavasta erityistuesta. Ehdotus sisältyy perhepolitiikan vastaista kehittämistä suunnitelleen toimikunnan muistioon (SOU 1964: 46). Se on periaatemietintö, eikä siinä ole esitetty mitään laskelmia kustannuksista eikä myöskään järjestelmän yksityiskohtia. Ehdotus muistuttaa lähinnä em. itävaltalaista järjestelmää. Hoitotukea maksettaisiin kaikille perheille, joissa on pieniä lapsia. Perhe saisi valita, jäisikö äiti hoitamaan itse lastaan, jolloin hän pitäisi hoitolisän ,äidinpalkkana,, vai menisikö hän ansiotyöhön ja käyttäisi hoitolisän lapsen päivähoidosta aiheutuviin kuluihin.

Näin ollen voitaneen sanoa, että äidinpalkaksi sanotut, perhekustannusten tasausjärjestelmiin kuuluvat tukimuodot ovat oikeastaan pienten tai useampien lasten kasvattajille tarkoitettuja korotettuja lapsilisiä, joiden avulla on pyritty tehostamaan perhekustannusten tasausta.

\section{Äidinpalkkaa koskevat esitykset Suomessa}

Aidinpalkkaa koskevia kirjoituksia on Suomessa esiintynyt jo 1950-luvulla, mutta eniten julkisuutta tämä asia sai silloin kun varatuomari Heikki v. Hertzen Perhekustannusten tasauskomitean puheenjohtajan ja Väestöliiton toiminnanjohtajan ominaisuudessa selosti ajankohtaisia perhepoliittisia uudistuksia Väestöliiton 20-vuotistilaisuudessa 14. 2. 61 . Tällöin hän esitti, että äidinpalkka on yhä selvemmin nousemassa ratkaisua vaativien suurten uudistusten joukkoon. Aidinpalkalla hän tarkoitti tukea, jota suoritettaisiin äidille niin kauan kuin hänellä on huollettavanaan pieni, esim. alle 3-vuotias lapsi. Tämän uudistuksen 
tarkoituksena olisi, ettei yksikään nainen, joka haluaa itse hoitaa pienokaisensa, joudu jättämään lastaan ja menemään ansiotyöhön taloudellisen pakon vuoksi. Aidinpalkan käytäntöönotto merkitsisi myös kotitaloudessa suoritettavan työn näkyvää arvostamista yhteiskunnan taholta (v. Hertzen 1961, 2).

Eräänä mahdollisuutena tämän järjestelmän asteittaiseksi toteuttamiseksi ajateltiin ns. ensisynnyttäjäperiaatetta, jonka mukaan äidinpalkkaa maksettaisiin sen voimaan tullessa vain sinä vuonna synnyttäville, kotiin jääville äideille. Ensimmäisenä vuonna tapauksia arvioitiin olevan n. 86.000 ja seuraavina vuosina äitien määrä kasvaisi noin 8-10.000:1la. Aidinpalkan suuruudeksi hahmoteltiin $70-100$ markkaa kuukaudessa. ${ }^{1}$

Uudelleen asia tuli esille, kun perhekustannusten tasauskomitea antoi mietintönsä toukokuussa 1966 (Komiteanmietintö 1966: A 7). Mietinnössä todettiin, että kaikille normaalisti lastenhoitoon soveltuville äideille pitäisi antaa mahdollisuus itse hoitaa lastaan ainakin lapsen kolmen ensimmäisen ikävuoden aikana. Lopullisessa ehdotuksessaan komitea katsoi, että äitiyssuojelun ja pientenlasten hoidon ja kasvatuksen tehostamiseksi olisi ryhdyttävä suorittamaan ns. äidinpalkkiota kotona oleville äideille, jotka itse hoitavat pienokaisensa aluksi yhden vuoden ja myöhemmin pitemmältä ajalta synnytysloman päättymisestä lukien. Eri uudistusten toteuttamisaikataulussa komitea sijoitti tämän uudistuksen vuosille 1973-75 sekä ehdotti, että kysymyksen lähempi selvittely annettaisiin joidenkin jo toiminnassa olevien taikka tarkoitusta varten asetettavien komiteoiden tehtäväksi.

Uutta virikettä äidinpalkkaa koskeva keskustelu sai kun samoihin aikoihin julkisuudessa selostettiin Espoossa tehtyjä suunnitelmia vähävaraisten perheiden alle kouluikäisten lasten kotihoidon tukemisesta. Kokeiluun ryhdyttiin vuoden 1967

1 Nämä ajatukset esitettiin myöskin tohtori Pekka Kuuselle, kun hän silloin valmisteli kirjaansa $\$ 60$-luvun sosiaalipolitiikka». (Kuusi 1961, 204-206). alkupuolella ja kotihoidon tukea maksetaan nyt pienituloisille perheille $50-300$ markkaa kuukaudessa. Avustusta myönnettäessä noudatetaan yksilöllisen huollon periaatetta ja avustuksen määrässä sosiaalilautakunnan ohjelukuihin perustuvaa tarveharkintaa. Tukea saavissa perheissä on vähintään kaksi alle kouluikäistä lasta, joista yksi on alle kolmivuotias. Aiti hoitaa itse lapsiaan. Vaikka tätä tukimuotoa julkisuudessa kutsutaan äidinpalkaksi, on sen pikemminkin katsottava olevan uusi ratkaisu lasten päivähoidon järjestelyssä, koska lastenseimien ylläpito tulee kunnalle huomattavan kalliiksi ja laitos voi hyvin palvella vain lähiympäristöään. Vuoden 1967 lopulla suoritettiin tätä tukea 40 äidille, joilla oli 95 lasta, ja seuraavaksi vuodeksi on varattu entistä suurempi määräraha. Myöskin muissa kunnissa on harkittu samantapaiseen järjestelmään siirtymistä.

Aidinpalkan maksamista on esitetty myös parin naisjärjestön taholta. Suomen Naisten Demokraattisen Liiton (1967) lausunnossa ehdotetaan, että valtiovalta ryhtyisi maksamaan lapsenhoitotukea äideille, joilla on alle 3-vuotias lapsi riippumatta siitä käykö äiti työssä vai ei. Tuki voitaisiin ehdotuksen mukaan toteuttaa suorittamalla alle 3 -vuotiaiden lasten lapsilisät nykyistä huomattavasti korkeampina. Suurituloisille ei kuitenkaan tätä tukea tulisi maksaa. Aidinpalkka-nimitystä eivät ehdotuksen tekijät hyväksy, koska äidin ja lapsen suhdetta ei voi verrata minkäänlaiseen palkkasuhteeseen. Mitään arviota lapsenhoitotuen määrästä ei esitetty.

Keskustapuolueen Naisten Uudenmaan piiri (1967) on myöskin jättänyt esityksen äidinpalkkion maksamisesta valtion toimesta tietyn tulorajan alapuolelle jääville alle 7-vuotiaiden lasten huoltajille. Perusteluina todetaan, ettei lapsilisä ole kyennyt korvaamaan lapsen aiheuttamaa kulutuksen lisäystä puhumattakaan lapsen hoidosta perheelle aiheutuvista menoista. Aloitteen tekijät eivät hyväksy sitä, että äidinpalkan suuruus määräytyisi sen mukaan, kuinka paljon äidille olisi maksettava, jotta hän jäisi kotiin, eikä sitä että 
se määräytyisi paikkakunnalla vallitsevien yleisten päivähuollosta aiheutuvien kustannusten tason mukaan, vaan parhaimpana vaihtoehtona pidetään yhtenäistä lapsilisään liittyvää järjestelmää.

Aidinpalkka-ajatus on tullut esille myöskin muutamassa toivomusaloitteessa, jotka on jätetty eduskunnalle vuonna 1966. Aron aloitteessa esitetään kiireellisiin toimenpiteisiin ryhtymistä tutkimuksen suorittamiseksi äidinpalkkakysymyksessä (Toiv. al. 915). Salaman aloitteessa yhteiskunnan varoista olisi maksettava korvaus työansion menetyksestä siinä tapauksessa, että ansiotyötä tekevä perheenhuoltaja haluaisi jäädä ansiotyöstään kotiin lasten ollessa pieniä (Toiv. al. 919). Lintilän aloitteessa esitetään jopa 2 milj. markan määrärahan ottamista budjettiin äidinpalkkion suorittamiseksi kotona oleville äideille, joilla on alle kouluiän olevia lapsia. Aloitteessa ei ole esitetty, millä perusteella tämä määräraha käytettäisiin tarkoitukseensa. (Toiv. al. 916).

Parissa muussa eduskunnalle jätetyssä edustaja-aloitteessa on korostettu sitä, että sairausvakuutuksen yhteydessä olisi määriteltävä lasta huoltavien äitien spalkkas ja näille äideille annettava nykyistä suurempi äitiysraha sekä päiväraha sairaustapauksissa. Mattilan aloitteessa kiinnitetään huomiota siihen, että aloitteen tekijän mielestä nykyisin maksetaan paremmassa asemassa oleville äideille suurempi avustus ja heikoimmassa asemassa oleville minimisumma. Äitiysraha olisi suoritettava kaikille synnyttäjille samansuuruisena. (Toiv. al. 917). Saalastin aloitteessa esitetään kiireellisiin toimenpiteisiin ryhtymistä äidinpalkan määrittämiseksi ja äitiyssuojelun perustamiseksi sille pohjalle. (Toiv. al. 918). Tässä aloitteessa tarkoitetaan äidinpalkalla lähinnä sitä, mitä Laura Harmaja nimittää perheenemännän tuloksi (1946, 189). Se olisi arvioitava korkeammaksi silloin, kun äiti hoitaa useaa lasta, ja yleensä suuremmaksi kuin ammattitaidottoman henkilön työpalkka, jonka mukaan päivärahan minimi tavallaan määräytyy ${ }^{1}$.

1 Minimipäiväraha, joka nyt on 5:20, vastaa 289 markan kuukausiansiota.
Mainittakoon tässä, että perhekustannusten tasauskomiteakin totesi äitiysrahan ja äidinpalkkion liittyvän toisiinsa siten, ettei ole tarkoituksenmukaista maksaa samanaikaisesti molempia (Komitean mietintö 1966: A 7, 33). Komitea esitti synnytysloman pidentämistä siten, että se alkaisi mikäli mahdollista kuusi viikkoa ennen synnytystä ja jatkuisi ainakin 12 viikkoa. ${ }^{2}$

\section{Motiivit}

Siinä muodossa kuin äidinpalkkajärjestelmä on esitetty otettavaksi käytäntöön Suomessa, ja myös Belgiassa, on päämotiivi ollut se, että suorittamalla äidinpalkkaa pikkulasten äideille, heille voitaisiin antaa mahdollisuus hoitaa lastaan niin kauan kuin se on pieni. Tätä puolestaan on perusteltu sillä, että lasten kehityksen kannalta on edullisinta, jos lapsi ensimmäisinä ikävuosinaan saa olla äidin hoidossa. Emotionaalinen kontakti ja läheisyys tiettyyn täyskasvuiseen henkilöön luo uudelle ihmisyksilölle turvallisuuden tunteen, jonka vaikutukset ulottuvat läpi koko elämän. Nämä toteamukset perustuvat eri puolilla maailmaa tehtyihin tutkimuksiin, jotka osoittavat mm, että laitoshoidossa, mutta myös kokopäivähoidossa ja seimissä olevat pikkulapset kehittyvät yleensä jonkinverran hitaammin ja ovat neurottisemmat kuin äidin hoidossa olevat lapset (mm. Ligue des familes... 1959, 9-10).

Aikaisemmin mainitussa ruotsalaisessa muistiossa esiintyvät myös yllä mainitut motiivit (SOU 1964: 36, 36-37). Siinä ei ole kuitenkaan haluttu jättää hoitotukijärjestelmän ulkopuolelle niitä perheitä, joissa äiti on ansiotyössä. Tällaista ehdotusta on ehkä katsottava sen tosiseikan valossa, että naisten osuus Ruotsin työ-

2 Todettakoon tässä yhteydessä, että Neuvostoliitossa työssä oleva äiti on oikeutettu lähes neljän kuukauden synnytyslomaan sekä että hän saa palkatonta lomaa - mikäli hän hoitaa lastaan - 12 kuukautta yhtäjaksoisesti synnytyksen jälkeen. Jos lapsi sairastuu äiti saa myös sairauslomaa, jonka aikana hänelle suoritetaan päivärahaa sosiaalivakuutuksen turvin. (Popova 1967, 29-30). 
voimasta on suuri ja että työvoiman puutteesta kärsivällä maalla ei ole varaa luoda järjestelmää, joka mahdollisesti supistaisi työvoiman saantia. Ehdotuksessa voi myös huomata ajatuksia, jotka pyrkivät lisäämään naisten valinnan vapautta: pikkulasten äidit voisivat tuntea hoitotuen moraalisena paineena, joka velvoittaisi heidät jäämään kotiin (SOU 1964, 38) sekä rajoittaisi heidän vapauttaan valita ansiotyön ja kodin välillä.

Kun naisten vapautusta ajavien piirien taholta korostetaan sitä, että äidinpalkan maksaminen kotonaoleville äideille rajoittaisi naisen vapaata valintaa kodin ja ansiotyön välillä, toiset taasen sanovat, että juuri tukemalla pelkästään kotona olevia äitejä luodaan mahdollisuus valita vapaasti - ilman taloudellista painetta, jonka perheen riittämättömät tulot aikaansaavat (Ligue des familles... 1957, 12).

Aidinpalkan käytäntöönottamista on myös perusteltu sillä, että äidinpalkka olisi näkyvä osoitus kotitaloustyön ja äidin kasvatustyön arvostamisesta yhteiskunnan taholta (mm. Toiv. al. 916/1966). Tällä tarkoitettaneen sitä, että jos kotitaloustyötä suorittavalle, lapsia huoltavalle äidille maksettaisiin yhteiskunnan toimesta stukirahaas, se olisi omiaan lisäämään kotitaloustyön arvostusta. Jos tätä tukea kutsuttaisiin äidinpalkaksi ja jos sen määrä jäisi esimerkiksi lapsilisän suuruiseksi, kuten Ranskassa, se saattaisi aiheuttaa väärinkäsityksiä. Kotitaloustyön arvostuksen lisäämisen sijasta voisi tulos ollakin päinvastainen: jos valtiovalta ei kerran arvosta kotitaloustyön tuottoa muutamaa kymmentä markkaa suuremmaksi, ei se sitä lienekään.

Aidinpalkkajärjestelmää on myös puolustettu sillä, että lastenhoito tulee monessa tapauksessa yhteiskunnalle kalliimmaksi lastentarhassa ja seimessä kuin kotona - varsinkin jos päivähoidossa on kaksi lasta tai useampia - koska äidin ansiotulot useasti ovat pienemmät kuin lasten päivähoidon aiheuttamat kokonaiskustannukset. Tähän ajatukseen perustuu myös Espoossa v. 1967 käytäntöön otettu lasten kotihoidon tuki.
Julkisuudessa on myös esitetty kannanottoja äidinpalkan toteuttamisen välttämättömyydestä mm. sillä perusteella, että lastenkotien ylläpitämiseen käytettävät varat voitaisiin maksaa suoraan äideille, jolloin he voisivat itse hoitaa lapsiaan eikä heidän tarvitsisi käydä ansiotyössä eikä antaa lastaan vieraan hoitoon. Onpa esitetty lapsilisien ja muiden perheavustusten tilalle äidinpalkkaa.

Todettakoon tässä yhteydessä, että äidinpalkan suorittamista maatalousväestölle ei voitane motivoida samalla tavalla kuin palkansaajille. Maatilan emännällä on käytännöllisesti katsottuna mahdollisuus valvoa lastaan myös silloin, kun hän on taloustöissä - ellei joku muu perheenjäsen hoida sitä. Toisaalta maatilan emännän työpäivä on pitempi ja raskaampi kuin muiden kotona olevien äitien, joten hänelle ajoittain jää hyvinkin vähän aikaa lapsensa hoitoon. Maatilan emännän osalta äidinpalkka olisi omiaan helpottamaan hänen työtaakkaansa, esim. työvoiman palkkaamiseen käytettynä - jotta hän voisi omistautua suuremmassa määrin äidin tehtäviin.

\section{Äidinpalkan suuruus}

Kuinka suuri olisi äidinpalkan oltava? Jonkinlaisen vastauksen tähän kysymykseen antaa Espoon kauppalassa vuonna 1965 tehty haastattelututkimus, joka edelsi nykyään siellä käytäntöön otettua järjestelmää. Tutkimus, jonka kohteena oli kauppalassa asuvia pienituloisia perheitä, osoitti halutun äidinpalkan vaihdelleen 155 mk:sta 400 mk:aan kuukaudessa; keskimäärin se oli $315 \mathrm{mk}$. Toivotun äidinpalkan keskimääräinen suuruus osui suurin piirtein samalle tasolle kuin äitien nettoansio. ${ }^{1}$ Koska tutkimuksen kohteena oli ollut vain pienituloisia perheitä, voitanee tämänsuuruisen äidinpalkan sanoa edustavan jonkinlaista toivottua minimi-

1 Nettoansiolla tarkoitetaan tutkimuksessa, jota on lähemmin selostettu tämän vuosikirjan kirjoituksessa sivuilla $7-28$ sitä summaa, joka palkasta jää jäljelle, kun verot, matkakulut ja lastenhoitomenot on vähennetty. 
äidinpalkkaa. Kuten aikaisemmin on esitetty äidinpalkkana maksetun tuen suuruus Espoossa on kuitenkin haluttua pienempi.

Mainittakoon että Ruotsissa ilmestyneessä mietinnössä todetaan, että jos hoitotuki otetaan käytäntöön sen täytyisi olla riittävän suuri vastaten esimerkiksi päiväkodin hoitokustannuksia (SOU 1964: $36,38)$. Belgiassa on myös päädytty lähinnä samanlaiseen tulokseen ja ehdotettu, että äidinpalkan olisi oltava noin neljännes työläisen keskimääräisestä palkasta (Ligue des familles ... 1959, 19). ${ }^{1}$

Väestöpoliittisessa Tutkimuslaitoksessa on laskettu, kuinka suureksi äidinpalkan kokonaiskustannukset tulisivat Suomessa, jos äidinpalkkaa maksettaisiin ainoastaan äideille, joilla on alle kolmen vuoden ikäisiä lapsia. Áitien lukumäärä on laskettu Ristimäen (1962) sekä Tilastollisen päätoimiston tekemien selvitysten mukaan vuosille 1965-75. Jos äidinpalkka olisi $315 \mathrm{mk} / \mathrm{kk}$, eli yhtä suuri kuin mitä Espoon pienituloiset äidit toivoivat, olisivat äidinpalkan kustannukset e.m. ajanjaksona - kun äidinpalkkaa maksettaisiin $\mathrm{kaikille}$ äideille, joilla on alle 3 vuoden ikäinen lapsi $-660-700$ milj. mk vuodessa. Tämä summa on jonkin verran suurempi kuin perhepoliittiset tulonsiirrot yhteensä vuonna 1966. Jos äidinpalkkaa suoritettaisiin ainoastaan kotona oleville äideille, supistuisivat kustannukset noin puoleen. Tämän suuruinen äidinpalkka on - koko maa huomioon ottaen - selvästi keskimääräistä ammattitaidottoman tai suppean ammattikoulutuksen saaneen naisen käytettävissä olevia tuloja suurempi.

Edellä esitetyistä kokonaiskustannuksista olisi vähennettävä ne korvaukset,

1 Meillä sisältyy lapsen hoidosta maksettava korvaus hoitomaksuun, joka maksetaan perheelle, johon on sijoitettu kunnan huostaan ottama lapsi. Hoitomaksu lienee nykyisin noin $100-150 \mathrm{mk} / \mathrm{kk}$. Sen lisäksi huoltaja saa tavanmukaiset lapsilisät ja-veronhuojennukset. Tarkoituksena on korvata kaikki lapsen aiheuttamat kulut, myöskin hoito, mutta hoidon osuutta ei voida erikseen määritellä niin mielenkiintoista kuin se tässä yhteydessä olisikin. joita perittäisiin hoitomaksuina niiltä äideiltä, jotka sijoittaisivat lapsensa päivähoitolaitoksiin. Tämä korvaus saattaisi olla äidin palkan suuruinen. Lisäksi olisi otettava huomioon se, että uusia lastenhoitolaitoksia ei ehkä tarvitsisi rakentaa tämän uuden järjestelmän vallitessa yhtä paljon kuin nykyisin on asian laita.

\section{Puolesta ja vastaan}

Ranskan esikuvan mukaan olisi äidinpalkkaa maksettava ainoastaan äideille, jotka jäävät kotiin hoitamaan lastaan, Ruotsissa ehdotetun järjestelmän mukaan olisi sen sijaan äidinpalkka suoritettava kaikille pikkulasten äideille. Tarkastelkaamme tässä eri järjestelmiä vastaan kohdistettua kritiikkiä.

Kotona olemisen määrittelemisen on epäilty aiheuttavan vaikeuksia ja tulkintamahdollisuuksia. Miten voidaan varmistua siitä, että äidinpalkka todella koituu lapsen hyväksi ja että äiti äidinpalkasta huolimatta ei mene töihin? Olisiko vaimolle, joka auttaa miestään kodin yhteydessä olevassa työpaikassa ja jolla siis työnsä ohella on hyviä mahdollisuuksia hoitaa ja valvoa lapsiaan, myönnettävä äidinpalkkaa vai ei? Olisiko muutaman tunnin ansiotyö sallittu? Esimerkiksi hammaslääkäri saattaa kotona suoritetulla muutaman tunnin päivittäisellä työllä ansaita yhtä paljon tai enemmän kuin ammattitaidoton nainen kokopäivätyössä. Ranskassa onkin todettu, että äidinpalkka on ollut lukuisten väärinkäytösten kohteena ja että kotona on ryhdytty tekemään erilaisia ansiotöitä, joista saatavat tulot on salattu (Laroque etc. 1961, 52).2

Jollei äidinpalkka suuruudeltaan vastaisi äidin ansiotuloja, voisi käydä niin, että riittämättömän äidinpalkan takia hänen olisi pakko mennä ansiotöihin kodin ulkopuolelle ja näin ollen järjestää lastensa hoito omalla kustannuksellaan. Varakkaat perheet, joissa äiti voisi olla

2 Aidinpalkkaa maksetaan nimittäin äidille, jos hänen o m a t tulonsa eivät kohoa yli määrän, joka on $1 / 3$ tai $1 / 2 \mathrm{em}$. pohjapalkasta eli noin $90-130 \mathrm{mk} / \mathrm{kk}$. (Hochard 1963, 89). 
kotona ilman äidinpalkkaakin, saisivat sen sijaan nauttia tästä tukimuodosta, vaikka he eivät olisikaan sen tarpeessa.

Mitä pienempi äidinpalkka on, sitä suurempi mahdollisuus on että juuri niissä perheissä, joissa äidinpalkkaa kipeimmin tarvittaisiin - sen riittämättömyyden takia - äidin täytyisi hankkia tarvitsemansa lisätulot ansiotyön avulla. Toisaalta on kaiketi keskituloisia perheitä, joissa äidin ei tarvitse aivan välttämättä olla ansiotyössä kodin ulkopuolella. Nämä perheet tervehtisivät luultavasti tyydytyksellä pienehköäkin äidinpalkkaa, joka merkitsisi lisätuloa perheelle ja joka samalla olisi sysäys äidin kotiinjäämisen hyväksi.

On todennäköistä, että mitä varakkaampi perhe on kysymyksessä sitä vähemmän tietty minimiäidinpalkka merkitsee tehtäessä päätöstä kotiin jäämisen ja ansiotyön välillä. Kun pienituloisissa perheissä tärkein työssäkäynnin syy on ansiotulojen hankkiminen (Seppänen 1967, 29), on luultavaa, että keski- ja suurtuloisissa perheissä työhönmenon motiivit ovat suuremmaksi osaksi muunlaatuisia kuin taloudellisia; äiti ei viihdy kotiäidin osassa, hän haluaa tavata ihmisiä jne. Mitä perusteellisemman ammattikoulutuksen hän on saanut sitä suuremmassa määrin hän halunnee myös käyttää hyväkseen sitä, joten perusteellisen ammattikoulutuksen saaneiden naisten piiristä löydettäneen suhteellisesti enemmän äitejä, jotka ovat ansiotyössä.

Espoossa tehdyn tutkimuksen mukaan kaksi kolmannesta haastatelluista ansiotyössä olevista äideistä ilmoitti pitävänsä kotiinjäämistä mahdollisena, jos heille maksettaisiin riittävän suuri äidinpalkka (Seppänen 1967, 86). Ranskassa tehty haastattelututkimus taas osoitti, ettei äidinpalkan korottaminen estäisi äitejä menemästä ansiotyöhön, mikäli he sitä halusivat. Ne äidit, jotka taloudellisista syistä ovat ansiotyössä, eivät todennäköisesti tyytyisi tukeen, joka muodostaisi vain osan heidän palkastaan. Toisaalta tutkimuksessa epäiltiin, etteivät äidit etukäteen varmuudella osanneet sanoa, miten he todella reagoisivat, jos äidinpalkkaa korotettaisiin (Hochard 1963, 90).

Kun äidin työhönmeno ei aiheudu vain taloudellisesta syystä, ei varmasti voida sanoa missä määrin äidinpalkka kannustaisi äitejä jäämään kotiin. Kun vielä otetaan huomioon, että tulevaisuudessa ennustettu työvoiman puute varmasti tulee lisäämään kotona oleviin nuorîn äiteihin kohdistuvaa painetta siirtyä ansiotyöhön, on näin ollen todennäköistä, että huomattava osa pikkulasten äideistä - mahdollisen äidinpalkkajärjestelmän käytäntöönottamisesta huolimatta - tulisi olemaan ansiotyössä kodin ulkopuolella. Onhan Talousneuvosto todennut aviovaimojen ja vanhusten muodostavan vastaisuudessa ainoan työvoimareservin (Mannermaa 1966, 16).

Perhekustannusten tasauskomitean mietinnön mukaan oli uusiin perhepoliittisiin toimenpiteisiin käytettävissä, pääasiassa äidinpalkkajärjestelmää varten, vuosina $1973-75 \quad 90-164$ miljoonaa $\mathrm{mk}$ (vuoden 1965 rahana). On näin ollen selvää, että äidinpalkan on oltava pienempi kuin mitä Espoon ansiotyössä olevat äidit toivoivat, jos äidinpalkkajärjestelmä ulottuisi kaikkiin kotona oleviin äiteihin, joilla on alle 3-vuoden ikäinen lapsi. Seurauksena voi tällöin olla, että äidinpalkkajärjestelmä juuri tulee sisältämään e.m. epäsosiaalisia piirteitä ja ettei äidinpalkalla tavoiteltua päämäärää saavutettaisi. Näin ollen näyttää siltä kuin äidinpalkan ulottuvuutta olisi rajoitettava.

Jos äidinpalkkaa ei haluttaisi maksaa kaikille kotona oleville äideille, voitaisiin sen maksu tehdä riippuvaksi perheen tulojen suuruudesta. Sosiaalipoliittiselta kannalta tulorajamenetelmä tuntuu tässä tapauksessa oikeutetulta, koska on kysymyksessä perhepoliittinen tukimuoto, jonka tulisi olla muita tasausmuotoja huomattavasti suurempi. Eräs tulorajamenetelmän heikkous on se, ettei etukäteen voida tietää, mihin summaan äidin työansiot nousevat. Eräissä tapauksissa saattaisi jopa käydä niin, että maksetut äidinpalkat jouduttaisiin perimään takaisin, jos tulot ylittävät vahvistetun enimmäismäärän. Eräs ratkaisu olisi se, että äidin- 
palkka suoritettaisiin samansuuruisena kaikille siihen oikeutetuille, mutta että se olisi veronalaista tuloa.

Viimeinen mahdollisuus olisi soveltaa tarveharkintaa, kuten Espoossa, jolloin voitaisiin yksityiskohtaisesti selvittää, mitkä perheet todella tarvitsevat äidinpalkkaa ja kuinka paljon. Toisaalta harkinnanvarainen järjestelmä voi aiheuttaa katkeruutta, jopa kielteisen asennoitumisen äidinpalkkajärjestelmään niiden keskuudessa, jotka jäävät syystä tai toisesta sen ulkopuolelle. Sitä paitsi tällainen menetelmä vaatisi suurehkon hallintokoneiston samalla kun tehokkaan kontrollin ylläpitäminen olisi vaikeata.

\section{Loppuhuomautuksia}

Aidinpalkalla on meillä eri yhteyksissä tarkoitettu ilmeisesti aivan eri asioita. Alunperin on äidinpalkalla tarkoitettu tietyssä iässä olevia lapsia hoitaville äideille maksettavaa sosiaaliavustusta tai korotettuja lapsilisiä (Ranskan yhden palkan lisä). Silloin on äidin oletettu jäävän kotiin lapsia hoitamaan. Myöhemmin on äidinpalkaksi kutsuttu myöskin sellaista tukea, jota on ajateltu maksaa kaikille pieniä lapsia hoitaville äideille, niillekin, jotka ovat ansiotyössä (hoitotukea). Eräissä tapauksissa on äidinpalkaksi kutsuttu myöskin pienituloisille, pieniä lapsia hoitaville äideille maksettavaa lasten kotihoidon tukea (Espoo) vaikka tämä tuki on lähinnä katsottava seimihoitoa korvaavaksi kotiavustukseksi.

Lisäksi on äidinpalkaksi kutsuttu lapsia kotonaan hoitavan äidin kotitaloustyön arvoa, jonka perusteella maksettaisiin sairausvakuutusjärjestelmän mukainen päiväraha ja äitiysraha. Lopuksi on äidinpalkaksi kutsuttu myös kotitaloustyötä suorittavalle äidille maksettavaksi ehdotettua stukirahaas. Tämän johdosta olisi pyrittävä mieluummin luopumaan äidinpalkan käsitteestä ja otettava käytäntöön eri nimitys jokaiselle edellä luetellulle tarkoitukselle.

Toisaalta on todettava, että eräitä nykyisin voimassa olevia tukimuotoja kehittämällä saatetaan osaksi päästä samoihin päämääriin, joihin edellä esitetyillä tukimuodoilla on pyritty. Ätiysrahan maksuaikaa pidentämällä voidaan olettaa, että entistä useampi äiti hoitaa lastaan sen ensimmäisten kuukausien aikana. Lapsia hoitavien äitien päivärahaa ja äitiysrahaa voitaisiin korottaa nykyisestä minimisummasta, ilman että sitä varten tarvitsisi ensin määritellä äidin kotitaloustyön arvo. Asumistuen kehittäminen, nuorten parien asunnonhankinnan tukeminen ja lapsilisien porrastaminen veisivät myöskin osittain samaan tulokseen.

\section{Kirjallisuusluettelo}

Ceccaldi, Dominique. Histoire des prestations familiales en France. Paris 1957.

Family Allowances. Developments in Family Allowances Legislation since 1953. ISSA Report XVI (Moniste). Geneva 1963.

v. Hertzen, Heikki. Perhepolitiikkamme kehittymiseen 1960-luvulla hyvät mahdollisuudet. Valtakunnansuunnittelu 2/1961.

Harmaja, Laura. Kotitalous kansantalouden osana. Helsinki 1946.

Hochard, Jacque. L'institution française des prestations familiales. Aubenas 1963.

Keskustapuolueen Naisten Uudenmaanpiiri. Keskustanaiset esittävät äidinpalkkajärjestelmää. Suomenmaa 25. 4. 1967.

Komiteanmietintö 1966: A 7. Perhekustannusten tasauskomitean mietintö. Helsinki 1966.

Kuusi Pekka. 60-luvun sosiaalipolitiikka. Porvoo 1961.

Laroque, Pierre, etc. Succés et faiblesse de l'effort social français. Paris 1951.

Ligue des familles nombreuses de Belgique. Congres doctrinal, Bruxelles 29-31 mai 1959. (Moniste). 1959.

Ligue des familles nombreuses de Belgique. Le Fondement de l'allocation de mère au foyer. Bruxelles 1965.

Mannermaa, Kauko. Arvio työvoiman kysynnän ja tarjonnan kehityksestä vuosina 1965-1980. Talousneuvoston sihteeristön selvityksiä n:o 1. (Moniste). Helsinki 1966. 
Popova, N. V. The Part Played by Women in Socialist Society. Moscow 1967. Ristimäki, Toini. Äitien työvoimaan kuuluvuus ja lasten hoito äidin työssä ollessa. Väestötutkimuksen Vuosikirja VII. Vammala 1962.

Seppänen, Virpi. Tutkimus alle kouluikäisten lasten päivähoidosta Espoon kauppalassa. (Moniste). Espoo 1967.
Statens offentliga utredningar (SOU) 1964: 36. Ökat stöd till barnfamiljer. Stockholm 1964.

Suomen Naisten Demokraattinen Liitto. Perhetukijärjestelmän tehokas laajentaminen. Kansan Uutiset 16. 2. 1967.

Valtiopäiville esitetyt toivomusaloitteet 915-919 vuonna 1966. 